Erratum

\title{
Erratum to: Singapore Medical Journal in the age of social media
}

$\mathrm{Ng} \mathrm{CL}$, Poh KK

Singapore Med J 2020; 61(10): 501-502; https://doi.org/10.11622/smedj.2020143

The DOI in the printed journal is incorrect. It should be https://doi.org/10.11622/smedj.2020143, and not https://doi.org/10.11622/ smedj.2020142. The online version of the article reflects the correct DOI.

http://doi.org/ 10.11622/smedj.2021067 